attitude in his spiritually-philosophical measuring, in his special method of co-operation of musical intonation and word.

Keywords: concept, national musical culture, the dominant concept.

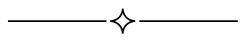

УДК 78.01+782.1/781.62

\title{
У Хуймінь
}

\section{ВОКАЛЬНЕ ІНТОНУВАННЯ ЯК ЧИННИК СЕМАНТИЧНОЇ ТИПОЛОГІї ОПЕРНОЇ ТВОРЧОСТІ}

У статті пропонується семантичний підхід до вокально-інтонаційного змісту опери, водночас доводиться актуальність типологічної характеристики жанрової форми опери з боку семантичних властивостей вокального інтонування. Виявляються основні рівні семантичної типології оперної творчості у їі естетичному та музично-інтерпретативному призначенні, характеризуються провідні способи оперного вокального інтонування (оперна вокальна поетика).

Ключові слова: оперне вокальне інтонування, оперна семантика, оперна вокальна поетика.

Вокальне інтонування є достатньо автономним виконавсько-інтерпретативним феноменом, що має власні технологічні показники та образні настанови. Але в контексті жанрової форми опери, тобто у системі оперних музично-виразових засобів воно набуває нових якостей, з одного боку, виявляючи залежність від інших компонентів оперного тексту, дієво-видовищного та словесно-поетичного, водночас набуваючи нової художньо-семантичної ваги, організаційної значущості. Тому воно виявляється здатним виступати в якості інструменту семантичної типології опери на іiї основних жанрово-композиційних рівнях.

Узагальнення положень досліджень [3; 9], пов'язаних з вивченням концептуальних сторін оперного твору, дозволяє дійти висновку, що перший рівень зумовлений визначенням найбільш загальної смислової скерованості оперного жанру, є мета-історичним та представляє характеристики оперної творчості за допомогою узагальнюючих визначень слів, драматичної дії, музичної експресії; дані поняття $є$ фундаментальними і наскрізними для всіх форм і видів опери. Даний рівень історично визначається в епоху бароко і класицизму; його го- 
ловним досягненням є затвердження як словесно-мовних, поетичнориторичних витоків оперного мелосу, так і формування його нових, специфічно-музичних, стилістичних рис.

Другий рівень представляє «велике» семантичне коло музики як коло жанрової семантики і стильової символіки, що дозволяє охопити оперну поетику в цілому, виявити ії власні естетичні установки, множинність обумовлених нею композиційних прийомів. Він дозволяє «дійти до тексту» до особливих образних ініціатив оперного вокального інтонування всередині оперної композиції, тобто виявляє різноманітність і рухливість образних функцій даного типу інтонування. Третій рівень представлений особливим «малим» семантичним діалогом, в його внутрішньо-стильовій та внутрішньо-стилістичній, також внутрішньо-текстовій формах. На цьому рівні відбувається створення нових комбінованих (стилістично контамінованих) видів вокального інтонування, водночас стабілізуються у функціональносемантичному сенсі його різновиди, що взаємодіють з різними внутрішньо-композиційними оперними формами та складовими цілісного оперного тексту. Тут головним результатом $є$ створення нових умов і у вокальному, і в оркестровому планах опери для поглибленої асиміляції вокально-інтонаційного комплексу в музично-тематичному змісті твору; цього свого семантичного результату опера досягає в період завершення своєї романтичної еволюції і відкриття наступних можливостей стильового здійснення.

В дослідженні Чжі Інь [9] зазначається, що однією з інтонаційнокомпозиційних сфер опери, народжених вокальним шляхом, постає речитатив, який сам виявляє множинність текстового втілення та виразово-смислових можливостей. Зокрема, він спроможний «доростати» до рівня показника цілісного оперного мови, набувати рис універсальності. Даний процес виявляє російська опера класико-романтичного періоду; саме на цей час укладено ії своєрідність, обумовлене, в тому числі, енциклопедичним накопиченням різних форм i способу словесної публічної промови, а також орієнтацією на психологічну поглиблення образу людини як соціально значущої, «великої» особистості. Інший напрямок еволюції оперного речитативу визначається в операх тих західноєвропейських композиторів (на кінець дев’ятнадцятого століття), які обирають контрастний тип оперного мелодійного мови, що дозволяє посилювати мелодраматичні (афективно-сугестивні) способи оперного діяння. В цьому випадку речитативні побудови концентруються, функціонально локалізують- 
ся, виявляють тенденцію семантичного протистояння аріозній кантилені, дозволяють знаходити особливі градації, семантичні «щаблі» в своїй стилістиці (інтенсивний «вердіївський шлях»)

Особливе місце в цьому відношенні займає оперна поетика П. Чайковського, який поглиблює всі тематичні ресурси опери мелодійним шляхом, тобто мелодійно збагачує й перетворює оперну мову, у тому числі насичуючи вокальним мелосом оркестрові партії та симфонічний розвиток, Але і він вдається до використання суто речитативних фігур (речитації, псалмодії, вигуків-реплік і т. п.) в якості афективних знаків граничної емоційної напруги, в цьому відношенні виявляючи стильову спільність з поетикою французької ліричної опери.

Слід уточнити також, що при всіх виявлених оперної жанровою формою тенденцій національного стильового розвитку, придбання оригінальних національно-стильових рис, в процесі еволюції типів вокального інтонування в опері дані тенденції не стають вирішальними.

Так, наприклад, К. М. Вебер, який був основоположником німецької національної опери і відкрив їі музично-стильові і стилістичні ресурси, представляє другий напрям розвитку речитативу (хоча Вагнер і знаходив в ньому свого попередника, але в інших відносинах, в плані вибору першоджерел лібрето і загальної розстановці образних сил). Мова йде не про дописані пізніше Г. Берліозом речитативні зв'язки, які замінили традиційні для зингшпілю словесно-розмовні епізоди, але про використання речитативних мелодраматичних прийомів всередині музичних сцен і про придбання ними спеціальних композиційних функцій

У стилістичних засадах оперного вокального інтонування можна знайти деякі національно-стильові показники, але вони обумовлені тими жанровими парадигмами європейської опери, які мають міжнаціональне значення, тобто розумінням жанрових завдань опери в іiі цілому. Одним з таких завдань стає посилення універсального художнього значення оперної форми, завдяки відтворенню в ній так званих «вічних» тем і образів.

Історично «Вільного стрілка» К. М. Вебера слід розглядати саме як романтичне оновлення німецького зингшпілю; композитор черпає з нього енергію безпосереднього, роздільного театрального дії [6-7]. I хоча про цю оперу судили як про твір, у якого немає власного стильового завдання, в ньому чітко позначаються музичні ресурси втілення сфер оперного вокального інтонування - від мовленнєвих 
словесних складових тексту, мелодекламації в момент небезпеки і загрози загибелі для головних героїв, до маршево-гімнічного затвердження перемоги моральної чистоти віри у лейтмотиві, який з теми Агати перетворюється на загальнонародну тему торжества добра. Прагнення до повного синтезу музики і драми, до точної і правдивої передачі поетичного слова стимулює композиторів не лише спиратися на вокально-декламаційну стилістику, а й поширювати іiї на оркестровий зміст опери.

Так, саме завдяки оркестровому розвитку в операх Р. Вагнера формується явище «нескінченної мелодії,, оскільки симфонічне звучання не знає зупинок (в межах оперного дії) і дозволяє з'єднувати між собою різні лейтмотивні побудови, причому більшість з них, як ми вже відзначали, пов'язані з декламаційним типом інтонування, тобто з тим феноменом публічних промов, який несе в собі деякі імпліцитні музичні властивості, розрахований на створення цілісного образу та на певну емоційно-психологічну сугестію.

Музично-тематичний процес, що відбувається в симфонічному змісті опер Р. Вагнера, свідчить про постійне оновлення, видозміну музичного образу драматичної дії, тому композитор відмовився від традиційних оперних арій і ансамблів з їх замкнутістю, ізольованістю один від одного і композиційною симетрією а на противагу оперному номеру висувається принцип вільної сцени, яка будується на постійно оновлюваному матеріалі і включає в себе різного вокально-інтонаційного вмісту епізоди, сольні та ансамблеві.

Основні оперні теми не тільки розробляються в оркестрі і оркестровими засобами; на основі інструментальних тембрів і фактурних рішень образи опери протиставляються, трансформуються, набувають нових значень, поліфонічно розробляються, в тому числі переводячи діахронні образні контрасти в симультанну фактурно-оркестрову вертикаль, таким чином, на основі лейтмотивного руху в оркестрі, виробляються монотематичні, водночас - полістилістичні, оперні показники художніх характерів.

Відомо, що будь-яка зріла опера Вагнера містить 10-20 лейтмотивів, наділених конкретним образним змістом, часто персоніфікованим. Музичне звучання стає пояснювальним фактором в загальній драматургії опер Вагнера. Дивно близьким, спорідненим Вагнеру, незважаючи на часті різко-негативні висловлювання на адресу німецького майстра, виявляється оперно-симфонічний метод М. Римського-Корсакова. Але цілісна концепція оперного тексту набуває 
в творчості Римського-Корсакова своєрідні риси. 3 одного боку, в оперній музиці російського композитора велику роль відіграють ті образи і образні сфери, які засновані на інструментальному способі інтонування та розвитку, виявляють новаторські фактурно-гармонійні прийоми, ладові рішення; вони адресовані поетиці чудесного, фантастичного, того, що дивує і навіть лякає. Деякі природні образи також змушують композитора шукати незвичайні виразові прийоми, оновлювати музичну мову, вводити дисонансну гармонійну сферу, зіштовхувати дві діатонічні системи, створювати ділянки «автономної нестійкості» - напружених функціональних тяжінь, тобто творити те саме «гармонійне зло», проти якого він так повставав, виявляючи невирішені і неприготовані дисонанси, «неправильні» функціональні послідовності акордів в творчості Вагнера і Мусоргського.

Одночасно Римський-Корсаков прагне до стійкої інтерпретації прийомів, до сталості їх семантичних функцій в різних композиційних контекстах, до їх символічного наповнення. Він рекомендує займатися тлумаченням художнього значення того чи іншого звукосполучення, акорду, гармонійної послідовності, вказуючи тим самим, що його музично-технологічні пошуки продиктовані вимогами нового смислу.

Таким чином, прагнення до повного синтезу музики і драми, до точної і правдивої передачі поетичного слова веде композиторів до опори на спеціальні стилістичні рішення не тільки в вокальних партіях, але і в оркестрово-симфонічному тексті опери, який є ії континуальній композиційною основою.

Саме в оркестровій партії опер Р. Вагнера концентруються основні лейтмотиви, утворюючи міцну мелодійну «мережу» з інтонаційного матеріалу вокально-декламаційного походження. Причому дані лейтмотиви, проходячи і розвиваючись в вокальних партіях, зберігають ті інструментальні масштаб і свободу звучання, які виникають 3 їх причетності до спільної симфонічної концепції опери; і це створює додаткові труднощі для вокалістів, які виконують опери байройтського майстра.

У музичній мові опер М. Римського-Корсакова найбільш яскрава і новаторська авторська риторика втілюється, перш за все, інструментально-оркестровим шляхом, в тому числі шляхом гармонійних нововведень у мелодійну сферу: мелодійна горизонталь, навіть будучи вокально викладеною, визначається вертикальним ладо-гармонійним «профілем» (гармонізується). 
Залежно від загальної сценічної ситуації, авторські риторичні прийоми (застосування зменшеного септакорду тритону, ладо-гармонійна ускладненість, автономна дисонансність, гармонії-мелодії) завжди свідчать про образну незвичайність, чудесну подію, можуть одночасно застосовуватися на декількох рівнях музичного тексту, в тому числі, розвиватися паралельно в вокальному та інструментальному планах оперної дії.

Оперна тема року в творчості П. Чайковського зберігає характер скупої речитації у всіх випадках іiі оркестрового та вокального використання, тобто зберігає свою загрозливу статику, змінюючи, нарощуючи тільки динамічну силу. В опері «Пікова дама» іiі розвиток організовано максимально послідовно, що стає одним з вирішальних факторів симфонізму даного твору.

Отже, вокальне інтонування може розглядатися як одна з рушійних сил у симфонізації опери, як за рахунок укрупнення іï оркестрового масштабу, так і завдяки широті та різноманітності образного змісту, стильового матеріалу оперної творчості.

Розвиток видів вокального оперного інтонування стає показовим для творчості тих композиторів, які виходили з пріоритету музичного начала по відношенню не тільки до словесного тексту, а й до драматичної дії, що спонукало їх посилювати драматичну дієвість саме музичної, зокрема вокальної, драматургії.

В цьому випадку вокальні інтонації можуть виступати «драматичним каталізатором» музичної події, посилюючи його напругу в критичні моменти, підкреслюючи урочисте призначення в завершальних кульмінаціях (наприклад, теми кохання в операх П. Чайковського, Р. Вагнера).

За спостереженням Д. Кірєєва, вже до середини XIX століття в оперному речитативі чітко позначилося коло однорідних явищ.

По-перше, речитатив глибше відображає процес самосвідомості героя, будучи своєрідним поглядом всередину себе; по-друге, він набуває тематичної значимості та починає відігравати все більш вагому роль в інтонаційно-тематичному розвитку опери; по-третє, він набуває здатності активно брати участь у вирішенні вищих завдань оперного цілого: стає засобом виявлення і розкриття духовно-світоглядної ідеї опери.

Такий речитатив, що відрізняється інтонаційно-тематичним та музично-смисловим змістом, тобто є семантично організованим, Д. Кірєєв пропонує називати рефлексивним. Автор в рівній мірі звер- 
тається до досвіду і західноєвропейської, і російської опери, але особливо його приваблює тип музичної драми, якому притаманне посилення засобів створення образу рефлексивної особистості та активне використання речитативно-декламаційної сфери [4].

Декламаційні прийоми стають показовими для окремих етапів розвитку вокальної оперної стилістики, свідчать про проникнення в неї афектованої театралізованої мови, але також пов'язані з афектацією самого вихідного музично-мовного, музично-поетичного, риторичного в своїй основі матеріалу. Декламаційність оперної мови розвивається на основі ії вокального походження; важливою стороною процесу трансформації декламаційного інтонування виявляється його взаємодія з кантиленою - спершу пісенно-мадригальною, потім аріозною. Так виникає декламаційно-мелодійний оперний стиль, який набуває значної стилістичної та семантичної широти, тому може розглядатися як показник індивідуального композиторського мовлення.

Так, Б. Ярустовський підкреслював, що в становленні оперного методу і оригінального оперного письма П. Чайковського велике значення мало те, що в таких операх, як «Пікова дама», «Отелло» або «Борис Годунов», вже містилося велике розмаїття видів вокального інтонування, в тому числі і в такій галузі, як мелодійно-декламаційний речитатив [10].

Розвиток вокального інтонування відбувається як процес постійного пошуку характерних особливостей оперної мови - спершу вокальної, потім і інструментально-оркестрової, шляхом відбору виразових прийомів зі сфер і словесно-мовних жанрів, і специфічного музичного жанрово-стилістичного змісту. При цьому вокальні партії насичувалися не тільки словесними, а й характерними музичними інтонаціями, тобто збагачувалися і розвивалися на основі художньо-виразової системи оперної музики як синтетичної естетичної форми. Провідною стороною нарощування їх семантичного потенціалу виступає вокально-виконавська творчість, мистецтво вокального інтонування.

\section{СПИСОК ЛИТЕРАТУРЫ}

1. Арановский М. Мышление, язык, семантика / М. Арановский // Проблемы музыкального мышления. - М., 1974. - С. 90-128.

2. Гадамер Х.-Г. Язык и понимание / Г. Гадамер // Актуальность прекрасного. - М. : Искусство, 1991. - С. 43-60.

3. Джан Бибо. Слово как символ в композиторской концептуализации музыкальной поэтики / Джан Бибо // Проблеми сучасності : культура, мистецтво, педагогіка : [зб. наукових праць / за заг. ред. В. Д. Філіппова]. - 
Луганськ : Луганський державний інститут мистецтв та культури, 2007. Вип. 8. - С. 34-44.

4. Киреев Д. Духовно-мировоззренческая функция речитатива в русской опере второй половины XIX века : дис....канд. искусств. : спец. : 17.00.02 музыкальное искусство / Дмитрий Зарифович Киреев. - Нижний Новгород, 2011. $-215 \mathrm{c}$.

5. Оголевец А. Слово и музыка в вокально-драматических жанрах / А. Оголевец. - М. : Музгиз, 1960. - 523 с.

6. Скорбященская О. «Что нам Вебер» или Мифы романтической историографии / О. Скорбященская // Музыкальная академия. - 1993. - № 1. C. $183-186$.

7. Скорбященская О. Чайковский и Вебер / О. Скорбященская // Советская музыка. - 1990. - № 12. - С. 101-105.

8. Тарасти Э. Музыка как знак и как процесс / Э. Тарасти // Homo musicus. Альманах музыкальной психологии : [сб. статей]. - М., 1999. - С. 61-78.

9. Чжи Инь. Оперная концепція как единство словесной и музыкальной интерпретации художественной идеи / Чжи Инь // Музичне мистецство і культура : Науковий вісник ОДМА імені А. В. Нежданової : [зб. наук. праць / гол. ред. О. В. Сокол]. - Одеса : Астропринт, 2012. - Вип. 17. - С. 308-316.

10. Ярустовский Б. Оперная драматургия Чайковского / Б. Ярустовский. - М. ; Л. : Гос. муз. издат, 1947. - 242 с.

У Хуйминь. Вокальное интонирование как фактор семантической типологии оперного творчества. В статье предлагается семантический подход к вокально-интонационному содержанию оперы, одновременно доказывается актуальность типологической характеристики жанровой формы оперы со стороны семантических свойств вокального интонирования. Выявляются основные уровни семантической типологии оперного творчества в его эстетическом и музыкально-интерпретативном назначении, характеризуются ведущие способы оперного вокального интонирования (оперная вокальная поэтика).

Ключевые слова: оперное вокальное интонирование, оперная семантика, оперная вокальная поэтика.

U Huymin. Vocal intonation as a factor in the semantic typology of an opera creation. Vocal intoning as factor of a semantic typology of opera creativity. In article semantic approach to vocal and intonational contents of the opera is offered, relevance of the typological characteristic of a genre form of the opera from semantic properties of a vocal intoning is at the same time proved. The main levels of a semantic typology of opera creativity in his esthetic and musical and interpretive appointment come to light, the leading ways of an opera vocal intoning (opera vocal poetics) are characterized.

Keywords: opera vocal intoning, opera semantics, opera vocal poetics. 